IZA DP No. 10031

The Elasticity of the Migrant Labor Supply:

Evidence from Temporary Filipino Migrants

Simone Bertoli

Jesús Fernández-Huertas

Moraga

Sekou Keita

July 2016 


\title{
The Elasticity of the Migrant Labor Supply: Evidence from Temporary Filipino Migrants
}

\author{
Simone Bertoli \\ CERDI, University of Auvergne, CNRS and IZA \\ Jesús Fernández-Huertas Moraga \\ Universidad Carlos III de Madrid, IAE-CSIC and IZA \\ Sekou Keita \\ CERDI, University of Auvergne
}
Discussion Paper No. 10031
July 2016

IZA
P.O. Box 7240
53072 Bonn
Germany

\author{
Phone: +49-228-3894-0 \\ Fax: +49-228-3894-180 \\ E-mail: iza@iza.org
}

\begin{abstract}
Any opinions expressed here are those of the author(s) and not those of IZA. Research published in this series may include views on policy, but the institute itself takes no institutional policy positions. The IZA research network is committed to the IZA Guiding Principles of Research Integrity.

The Institute for the Study of Labor (IZA) in Bonn is a local and virtual international research center and a place of communication between science, politics and business. IZA is an independent nonprofit organization supported by Deutsche Post Foundation. The center is associated with the University of Bonn and offers a stimulating research environment through its international network, workshops and conferences, data service, project support, research visits and doctoral program. IZA engages in (i) original and internationally competitive research in all fields of labor economics, (ii) development of policy concepts, and (iii) dissemination of research results and concepts to the interested public.
\end{abstract}

IZA Discussion Papers often represent preliminary work and are circulated to encourage discussion. Citation of such a paper should account for its provisional character. A revised version may be available directly from the author. 


\section{ABSTRACT}

\section{The Elasticity of the Migrant Labor Supply: Evidence from Temporary Filipino Migrants*}

The effect of immigration on host and origin countries is mediated by the way migrants take their labor supply decisions. We propose a simple way of integrating the traditional random utility maximization model used to analyze location decisions with a classical labor demand function at destination. Our setup allows us to estimate a general upper bound on the elasticity of the migrant labor supply that we take to the data using the evolution of the numbers and wages of temporary overseas Filipino workers between 1992 and 2009 to different destinations. We find that the migrant labor supply elasticity can be very large. Temporary migrants are very reactive to economic conditions in their potential destinations.

JEL Classification: F22, J31, J38, J61, O15

Keywords: international migration, temporary migration, labor supply elasticity, multilateral resistance to migration

Corresponding author:

Simone Bertoli

CERDI

University of Auvergne

Bd. F. Mitterrand, 65

F-63000 Clermont-Ferrand

France

E-mail: simone.bertoli@udamail.fr

\footnotetext{
* We would like to thank David McKenzie, Caroline Theoharides and Dean Yang for making available the dataset on temporary Filipino migration used in their paper (McKenzie et al., 2014); Simone Bertoli acknowledges the support received from the FERDI and the Agence Nationale de la Recherche of the French government through the program "Investissements d'avenir" (ANR-10-LABX-14-01); Jesús Fernández-Huertas Moraga received financial support from the Support from the Ministerio de Economía y Competitividad (Spain), grant MDM 2014-0431, and Comunidad de Madrid, MadEco-CM (S2015/HUM-3444). The usual disclaimers apply.
} 


\section{Introduction}

As long as country of birth represents the largest source of inequality in the world (Milanovic, 2005), it is only natural that individuals try to improve their living conditions by changing their country of residence. The extent to which they do so is going to affect welfare in general, and the labor market in particular, both at their origin country and at their chosen destinations. $^{1}$ Furthermore, the temporary admission of foreign workers, as opposed to permanent immigration, has been advocated by Pritchett (2006) as a way for "breaking the gridlock" on the mobility of labor across borders, which could contribute both to alleviate poverty and to reduce the inequalities documented by Milanovic (2015).

The objective of our paper is to analyze how such a market for temporary migrant labor reacts to variations in economic conditions at destination through adjustments in the labor supply of migrants. Do foreign workers admitted on a temporary basis earn higher wages in good economic times, or is the labor market equilibrium restored only through an increase in the scale of temporary migration flows? Providing a convincing empirical answer to these questions, which have been already analyzed by McKenzie et al. (2014), requires dealing with a key analytical challenge, namely the interaction of the labor supply and the labor demand in each possible location. It is now well established in the literature that ignoring the threat posed by correlated variations in the labor market conditions across destinations can produce biased estimates (Bertoli and Fernández-Huertas Moraga, 2013, 2015), a potentially relevant threat for the analysis proposed by McKenzie et al. (2014) given the time and geographical composition of their sample of destinations for temporary Filipino migrants.

The contribution of this paper is to show how to deal with this analytical challenge through the introduction of the random utility maximization (RUM) model in a canonical analysis of the functioning of the labor market. We reveal how the gravity elasticities derived from the RUM model cannot be directly interpreted as labor supply elasticities since they are affected by the evolution of labor demand. However, as long as the component of labor demand idiosyncratic to each destination country can be empirically isolated, a general upper bound on the migrant labor supply elasticity can be computed by dividing the elasticity of migration flows with respect to labor demand shocks by the elasticity of migrant wages

\footnotetext{
${ }^{1}$ See Borjas (2003) and Ottaviano and Peri (2012) for examples of different views on how the labor market at destination is affected by emigration; see Mishra (2007) for an example on how the labor market at origin can be affected.
} 
to labor demand shocks. In order to identify destination-specific labor demand shocks, we propose using multifactor error models (Pesaran, 2006; Bai, 2009), which allow us, for example, to clean the estimated effect of the evolution of the GDP in a given country from its spurious correlation with the evolution of the GDP in alternative destinations for the migrants.

We apply this strategy to the computation of the elasticity of the migrant supply of temporary Filipino workers. To this end, we draw on panel data on the number of overseas Filipino workers and on their wages to 54 destination countries between 1992 and 2009 collected by the Philippine Overseas Employment Administration (POEA) and which have been processed by McKenzie et al. (2014).

We estimate that the upper bound on the labor supply elasticity of temporary Filipino workers is as large as 8.57. To our knowledge, this is the largest ever estimated labor supply elasticity and only some of the estimates in Kleven et al. (2014) for professional footballers (elasticity of 3 for top quality players) come anywhere close to it. ${ }^{2}$ A common feature of the football market and the migrant labor market that we analyze is the relevance of mobility restrictions, on the side of the demand for football players, and on supply itself in the case of temporary migrant workers. We interpret this large elasticity as proof of the ability of prospective migrants to choose among many alternative competing destinations, which is contrary to the image of temporary workers taking whatever job they are offered.

We show that both the wages and the number of temporary Filipino migrants are procyclical. Dealing with the threat to identification posed by the correlated variations in macroeconomic conditions across destinations proves to be crucial for obtaining an unbiased estimate of the responsiveness of the scale of temporary migration and of the wages of Filipino migrants with respect to real GDP at destination, our source of destination-specific demand shocks. When this threat to identification is not dealt with, the two estimated coefficients are biased in opposite directions, as predicted by a standard market-clearing model for temporary migrant labor. Furthermore, the bias is larger for the estimated coefficient of real GDP in the migration rather than in the wage equation, a finding that can be accounted for by an elastic labor demand for temporary migrant labor. If we ignore the correlation in GDP shocks across destination countries, which gives rise to what Bertoli and FernándezHuertas Moraga (2013) have termed multilateral resistance to migration bias, our estimated

\footnotetext{
${ }^{2}$ See the classical review in MaCurdy et al. (1990) or more recent ones such as Chetty et al. (2013).
} 
elasticity goes down to 3.34 .

While our labor supply elasticity estimates are large from the point of view of the literature using tax rate changes to estimate labor supply functions, they are very similar to the reduced form findings from the estimation of international migration gravity models (Beine et al., 2016). With respect to McKenzie et al. (2014), we reproduce their estimate on the migration equation but consider it downward biased because they ignore the confounding influence of the effect of GDP in alternative destinations. Contrary to them, we find a positive and significant relationship between GDP and migrant wages at destination.

Our paper is also related to the growing literature analyzing emigration from the Philippines, one of the main origin countries for emigration in the world. This goes back to the classic papers by Dean Yang (Yang, 2006, 2008), whose tradition has recently been continued by the already cited McKenzie et al. (2014), Theoharides (2015), Cortes (2015) or Licuanan et al. (2015).

The rest of the paper is structured as follows: Section 2 discusses the theory that underlies the estimation of the labor supply elasticity, and Section 3 briefly introduces the data. Then, Section 4 summarizes the econometric results and Section 5 draws the main conclusions.

\section{Theoretical framework}

We build on a simple labor market model to discuss the conditions under which it is possible to recover empirically the labor supply elasticity of temporary Filipino migrants. Specifically, we focus on the implications of different distributional assumptions on the unobserved component of the underlying static RUM model describing the location-decision problem faced by potential migrants. ${ }^{3}$

\subsection{The market for temporary migrant labor}

Consider a simple setup describing the labor market equilibria for temporary migrants in $j=1, \ldots, N$ destination countries at different points in time $t=1, \ldots, T$. ${ }^{4}$ The inverse demand function $D_{j}\left(y_{j t}\right)$ for temporary migrant labor in each destination $j$ at time $t$ depends on the

\footnotetext{
${ }^{3}$ Details on the underlying model are reported in the Appendix A.1.

${ }^{4}$ Potential migrants leave from a single origin country.
} 
real GDP $y_{j t}$ and on the number of migrants $m_{j t}$ that move on a temporary basis from the origin country to destination country $j$ at time $t$. Let $\mathbf{w}_{t}=\left(w_{0 t}, w_{1 t}, \ldots, w_{N t}\right)^{\prime}$ and $\mathbf{c}_{t}=\left(0, c_{1 t}, \ldots, c_{N t}\right)^{\prime}$ be two vectors that gather migrants' wages and bilateral migration costs at time $t .{ }^{5}$ The supply of temporary migrant labor can be derived from an underlying static random utility maximization model that describes the location-decision problem faced by potential migrants, which represents the standard micro-foundation of a gravity equation for migration (Beine et al., 2016). Specifically, the utility attached to each location $j$ at time $t$ can be decomposed into a deterministic component of utility that depends on the logarithm of the wage $w_{j t}$ and on bilateral migration $\operatorname{costs} c_{j t}$, and an individual-specific stochastic component $\epsilon_{i j t}$. Assuming that $\epsilon_{i j t}$ follows an independent and identically distributed Extreme Value Type-1 distribution, it can be shown (see McFadden, 1974) that the expected value of the labor supply $m_{j t}$ depends on the wage $w_{j t}$, on bilateral migration costs $c_{j t}$, and on the expected value from the choice situation that potential migrants face at time $t$ (Small and Rosen, 1981), which is a function of $\mathbf{w}_{t}$ and $\mathbf{c}_{t}$. Under the assumption that the bilateral migration costs follow an identical time profile, the labor supply for each destination country $j$ at time $t$ depends on a country-specific constant capturing time-invariant shifts in wages and migration costs, and on common shocks that vary only over time but not across destinations.

Figure 1 plots the (logarithmic transformation of) the inverse demand function $D_{j}\left(y_{j t}\right)$ and the inverse supply function $S_{j}\left(\mathbf{w}_{t}, \mathbf{c}_{t}\right)$ for migrant labor in destination $j$ described above in the $\left(\ln m_{j t}, \ln w_{j t}\right)$ space. It shows that it is possible to recover the labor supply elasticity as long as changes in labor demand independent from changes in labor supply in other destinations can be isolated. This is explored in the next subsection.

\section{$2.2 \quad$ Reduced form regressions}

From the model sketched above, it is straightforward to derive the following reduced-form equations allowing to identify the scale of migration and the elasticity of migrants' wages with respect to the real GDP at destination: ${ }^{6}$

$$
\ln \left(m_{j t}\right)=\psi_{m} \ln \left(y_{j t}\right)+\boldsymbol{\beta}_{m}{ }^{\prime} \mathbf{d}_{j}+\boldsymbol{\gamma}_{m}{ }^{\prime} \mathbf{d}_{t}+\varepsilon_{j t}^{m}
$$

\footnotetext{
${ }^{5}$ We let $w_{0 t}$ denote the wage in the origin country at time $t$, and we normalize the first element of $\mathbf{c}_{t}$, which represents the cost of staying at the origin, to zero.

${ }^{6}$ See Section A.1 of the Appendix for details on how the equations are obtained from the model.
} 
Figure 1: Inverse demand and supply functions for migrant labor

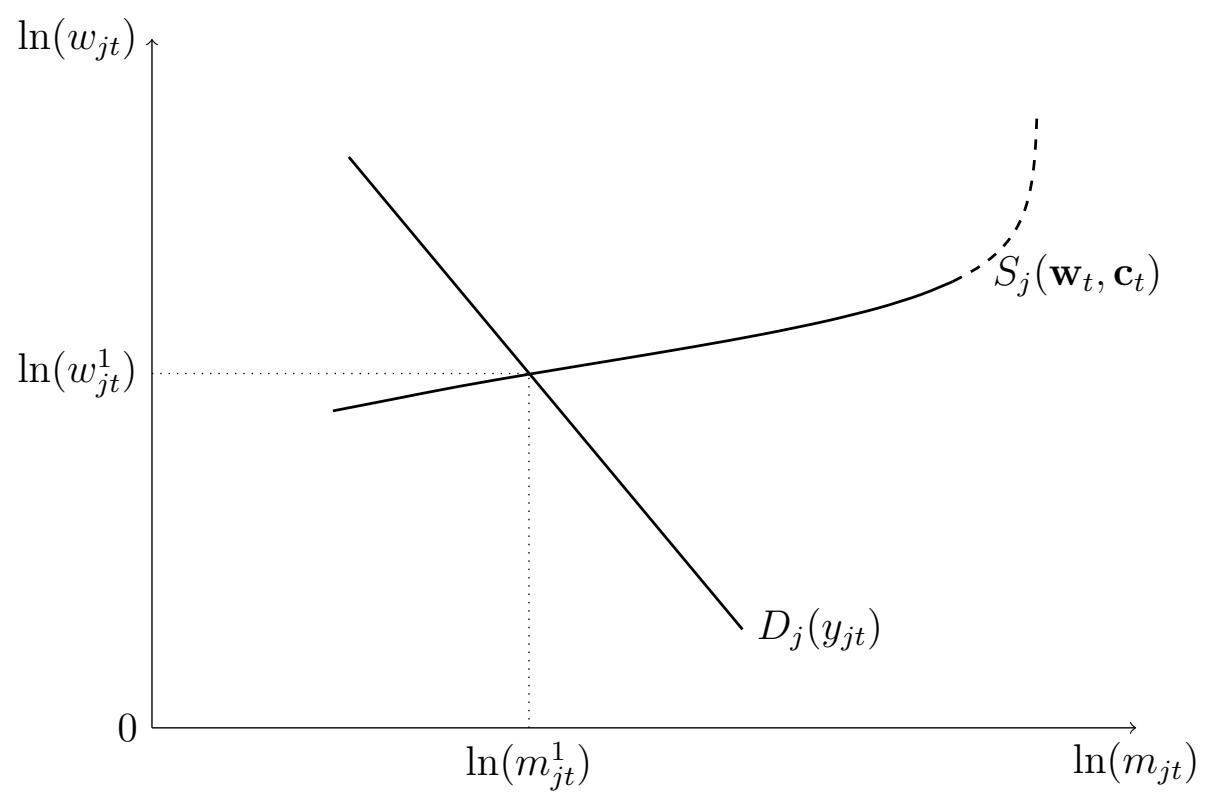

and:

$$
\ln \left(w_{j t}\right)=\psi_{w} \ln \left(y_{j t}\right)+\boldsymbol{\beta}_{w}{ }^{\prime} \mathbf{d}_{j}+\boldsymbol{\gamma}_{w}{ }^{\prime} \mathbf{d}_{t}+\varepsilon_{j t}^{w},
$$

where $w_{j t}$ in (2) is either the mean or the median wage earned by the $m_{j t}$ migrants and $\mathbf{d}_{j}$ and $\mathbf{d}_{t}$ are two vectors of destination and time dummies. Destination dummies $\mathbf{d}_{j}$ control for the dyadic time-invariant component of migration costs, and for the destination-specific timeinvariant level of the demand for temporary migrant labor. Time dummies $\mathbf{d}_{t}$ control for the factors that exert a time-varying influence on $\ln \left(m_{j t}\right)$ and $\ln \left(w_{j t}\right)$ for any $j=1, \ldots, N$, such as demographic factors at origin or variations in macroeconomic conditions in all potential destinations and at origin. It is then immediate to recover an estimate of the labor supply elasticity parameter as: ${ }^{7}$

$$
\widehat{\beta}=\frac{\widehat{\psi}_{m}}{\widehat{\psi}_{w}}
$$

\footnotetext{
${ }^{7}$ We will be referring to $\widehat{\beta}$ as the labor supply elasticity, even though formally it is just an upper bound of the true elasticity (Bertoli and Fernández-Huertas Moraga, 2015).
} 


\subsection{Correlated variations in real GDP across destinations}

The evolution of macroeconomic conditions across alternative destinations might be (positively or negatively) correlated; specifically, a pattern of predominantly positive correlations entails that a rightward shift of the curve $D_{j}\left(y_{j t}\right)$ would be associated with a leftward shift of the curve $S_{j}\left(\mathbf{w}_{t}, \mathbf{c}_{t}\right)$, as potential migrants would face higher wages in alternative destinations. This would produce an upward bias in the induced variation in migrants' wages, and a downward bias in the effect on the scale of migration flows to $j$, if the correlated shift in the migrant labor supply is not controlled for, as depicted in Figure 2. This, in turn, would imply that $\widehat{\beta}$ would be downward biased.

Figure 2: Correlation between shifts in the inverse demand and supply functions

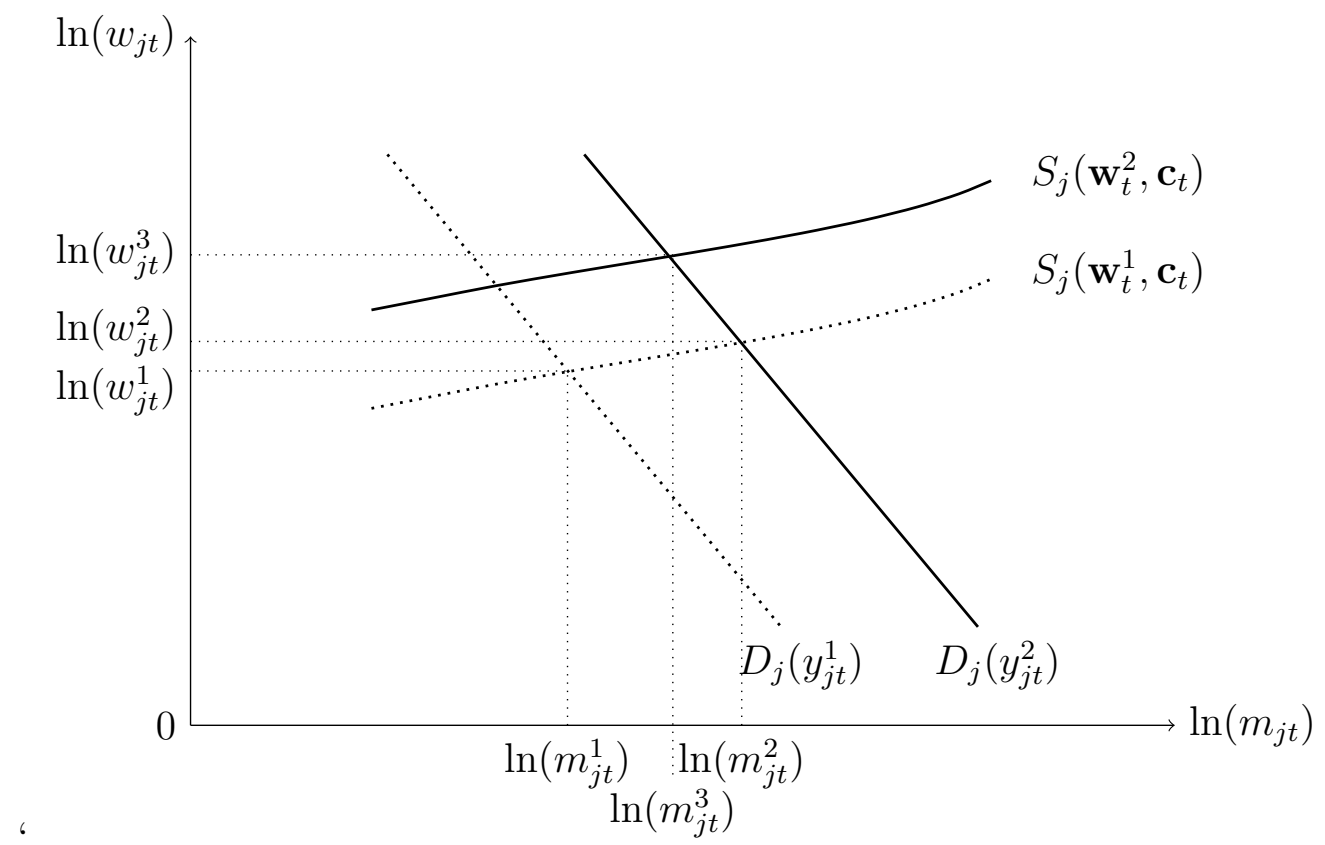

Note: the figure is drawn assuming a positive correlation in the evolution of real GDP across destinations.

However, this does not pose a serious threat to identification under the distributional assumptions à la McFadden (1974), as these entail that the inverse supply curves for different destinations are identical up to a constant. Hence, this confounding effect is fully controlled for in the estimation of (1) and (2) through the inclusion of time dummies $\mathbf{d}_{t}{ }^{8}$ This also

\footnotetext{
${ }^{8}$ This is, a fortiori, the case in the presence of binding minimum wages, as shifts in the labor supply are
} 
applies under the distributional assumptions of Ortega and Peri (2013), which allow for unobserved individual heterogeneity in the preferences for migration, as the function that describes the influence of the attractiveness of alternative destinations on the migrant labor supply is still invariant across destinations.

Correlated variations in macroeconomic conditions across destinations pose a more serious threat to identification under more general distributional assumptions, which allow for differences in the elasticities of substitution across different pairs of destination countries (Bertoli and Fernández-Huertas Moraga, 2013, 2015), and that can be motivated by an incomplete specification of the deterministic component of location-specific utility. ${ }^{9}$ Imagine, for instance, that potential Filipino migrants perceive South Korea $(j)$ and Malaysia $(h)$ as close substitutes, while the United States $(k)$ represent a distant substitute for both destinations: an increase in the attractiveness of Malaysia induces a proportional reduction in the supply of Filipino migrants to South Korea at the contracted wage $w_{j t}$ that exceeds the corresponding proportional reduction in the supply of Filipino migrants to the United States at the contracted wage $w_{k t}$. In other terms, the inverse supply functions $S_{j}\left(\mathbf{w}_{t}, \mathbf{c}_{t}\right)$ and $S_{k}\left(\mathbf{w}_{t}, \mathbf{c}_{t}\right)$ do not follow an identical time profile over time, and the use of time dummies $\mathbf{d}_{t}$ no longer suffices to control for the shifts over time of the inverse supply functions.

If this threat is not adequately controlled for, then the error terms of (1) and (2) will be serially correlated, as the attractiveness of alternative destinations is likely to evolve slowly over time, and correlated across destinations if some destination countries have similar sets of destinations that are perceived as close substitutes to each of them, e.g., Malaysia might be a close substitute for both South Korea and Indonesia. The non-spherical nature of the error term can produce inconsistently estimated standard errors, and, more importantly, it gives rise to an endogeneity problem for $\ln \left(y_{j t}\right)$ when the economic shocks in destination $j$ are correlated with the economic shocks in other destinations that are close substitutes to $j$. This can create a serious threat to identification, as shifts in the labor demand curve in destination $j$ can be correlated with shifts in the labor supply due to changes in the attractiveness of other destinations. Specifically, if there is a positive correlation in the evolution of economic conditions in destinations that are regarded as close substitutes, then a rightward shift in the labor demand curve is associated with a leftward shift in the supply

immaterial as long as the minimum wage remains binding.

${ }^{9}$ This could occur, for instance, if the assumption that $c_{j t}=c_{j}+f_{t}$ for all $j \in D$ is incorrect, as the relative accessibility of different destinations varies over time. 
curve, leading to a downward bias in the estimate of $\psi_{m}$ and to an upward bias in the estimate of $\psi_{w}$. This situation is depicted in Figure 2. The relative importance of the bias on the two coefficients of interest depends on the elasticity of the labor demand schedule. If the labor demand is flatter, and hence more elastic, then the correlation in macroeconomic shocks across destinations will induce a larger bias in the estimate of $\psi_{m}$ than of $\psi_{w}$. ${ }^{10}$ The opposite pattern of correlation would reverse the direction of the bias in the estimation of $\psi_{m}$ and $\psi_{w}$.

\subsection{Dealing with the threat to identification}

Bertoli and Fernández-Huertas Moraga (2013) demonstrate that the Common Correlated Effects, CCE, estimator proposed by Pesaran (2006) allows us to control for the threat to identification posed by the dependence of the migrant labor supply on the attractiveness of alternative destinations. ${ }^{11}$ The CCE estimator calls for adding a set of auxiliary regressors corresponding to destination-specific effects of the cross-sectional averages of the dependent variable and of all the independent variables in the model. In the case of the reduced-form migration regression, this amounts to estimating:

$$
\ln \left(m_{j t}\right)=\psi_{m} \ln \left(y_{j t}\right)+\boldsymbol{\beta}_{m}{ }^{\prime} \mathbf{d}_{j}+\boldsymbol{\phi}_{m j}{ }^{\prime} \mathbf{z}_{t}+\epsilon_{m j t}
$$

where: ${ }^{12}$

$$
\mathbf{z}_{t}=\frac{1}{N}\left(\sum_{j=1}^{N} \ln \left(m_{j t}\right), \sum_{j=1}^{N} \ln \left(y_{j t}\right)\right)^{\prime} .
$$

Similarly, for the wage regression we can estimate:

$$
\ln \left(w_{j t}\right)=\psi_{w} \ln \left(y_{j t}\right)+\boldsymbol{\beta}_{w}{ }^{\prime} \mathbf{d}_{j}+\boldsymbol{\phi}_{w j}{ }^{\prime} \mathbf{z}_{t}+\epsilon_{w j t} .
$$

We can observe that (4) reduces to (1) if we impose the restriction that $\boldsymbol{\phi}_{m j}=\boldsymbol{\phi}_{m}$ for any $j{ }^{13}$ and that (5) reduces to (2) if $\phi_{w j}=\phi_{w}$. In this sense, the fixed effects models

\footnotetext{
${ }^{10}$ If the labor demand is infinitely elastic, i.e., $\phi=0$, then the presence of correlated shocks does not induce a bias in the estimation of $\psi_{w}$.

${ }^{11}$ Notice that the CCE estimator can accommodate serial correlation and cross-sectional dependence in the error term (Pesaran and Tosetti, 2011).

${ }^{12}$ If weights are used in the estimation, then auxiliary regressors are computed through weighted crosssectional averages.

${ }^{13}$ With this restriction, we have that $\widehat{\phi}_{m}=\left(1,-\widehat{\psi}_{m}\right)^{\prime}$, as the inclusion of time dummies $\mathbf{d}_{t}$ is equivalent to
} 
in (1) and (2) are nested in the CCE estimator. Hence, we will refer to (4) and (5) as the unrestricted specifications and to (1) and (2) as the restricted specifications. In terms of the interpretation of the estimates, this is the difference between assuming that all destination countries are equally substitutable for potential migrants, as in Ortega and Peri (2013), and assuming different patterns of substitution across destinations for potential countries, as in Bertoli and Fernández-Huertas Moraga (2013, 2015). The more complicated error structure would also affect the computation of the labor supply elasticity in equation (A.10). Still, it would not change the interpretation of the parameter $\widehat{\beta}=\widehat{\psi}_{m} / \widehat{\psi}_{w}$ as an upper bound on the true elasticity.

\section{$3 \quad$ Data and descriptive statistics}

We use the bilateral data on the scale of temporary Filipino migration and on migrants' wages between 1992 and 2009 collected by the Philippines Overseas Employment Administration (POEA). ${ }^{14}$ Our analysis draws on the replication files by McKenzie et al. (2014), which include information on the (total and gender-specific) number of new hires and on the median and mean hiring wages to 54 destination countries. ${ }^{15}$ New hires are defined as all the instances in which land-based overseas Filipino workers sign a temporary contract with a new employer; this definition thus includes both first-time migrants and migrants that change their job at destination. ${ }^{16}$ The destination countries included in the sample recorded a positive number of new hires in each year, and accounted for no less than 85 percent of the total number of new hires of Filipino workers in the world for every year between 1992 and 2009.

Figure 3 plots the evolution of the total number of new hires and the mean of the nominal wage reported in the contracts between 1992 and 2009 for our sample of destination countries. The number of new hires increases, although not steadily so, over time, oscillating between

taking the difference of the dependent and of the independent variable(s) from the respective cross-sectional averages.

${ }^{14}$ Migrants' average monthly wages $w_{j t}$ are measured in current US dollars.

${ }^{15}$ We rely on the logarithm of the mean wage, as in Ottaviano and Peri (2012) and in McKenzie et al. (2014), even though this choice is regarded "unconventional" by Borjas et al. (2012). The underlying individual wages that we would need to compute the mean of the log wage are not publicly available. This choice has the advantage of making our results directly comparable with those from McKenzie et al. (2014).

${ }^{16}$ McKenzie et al. (2014) report that new hires represent 38 percent of all the contracts processed by the POEA between 1998 and 2009, with rehires constituting the remainder. 
Figure 3: Number of new hires and mean wage, 1992-2009

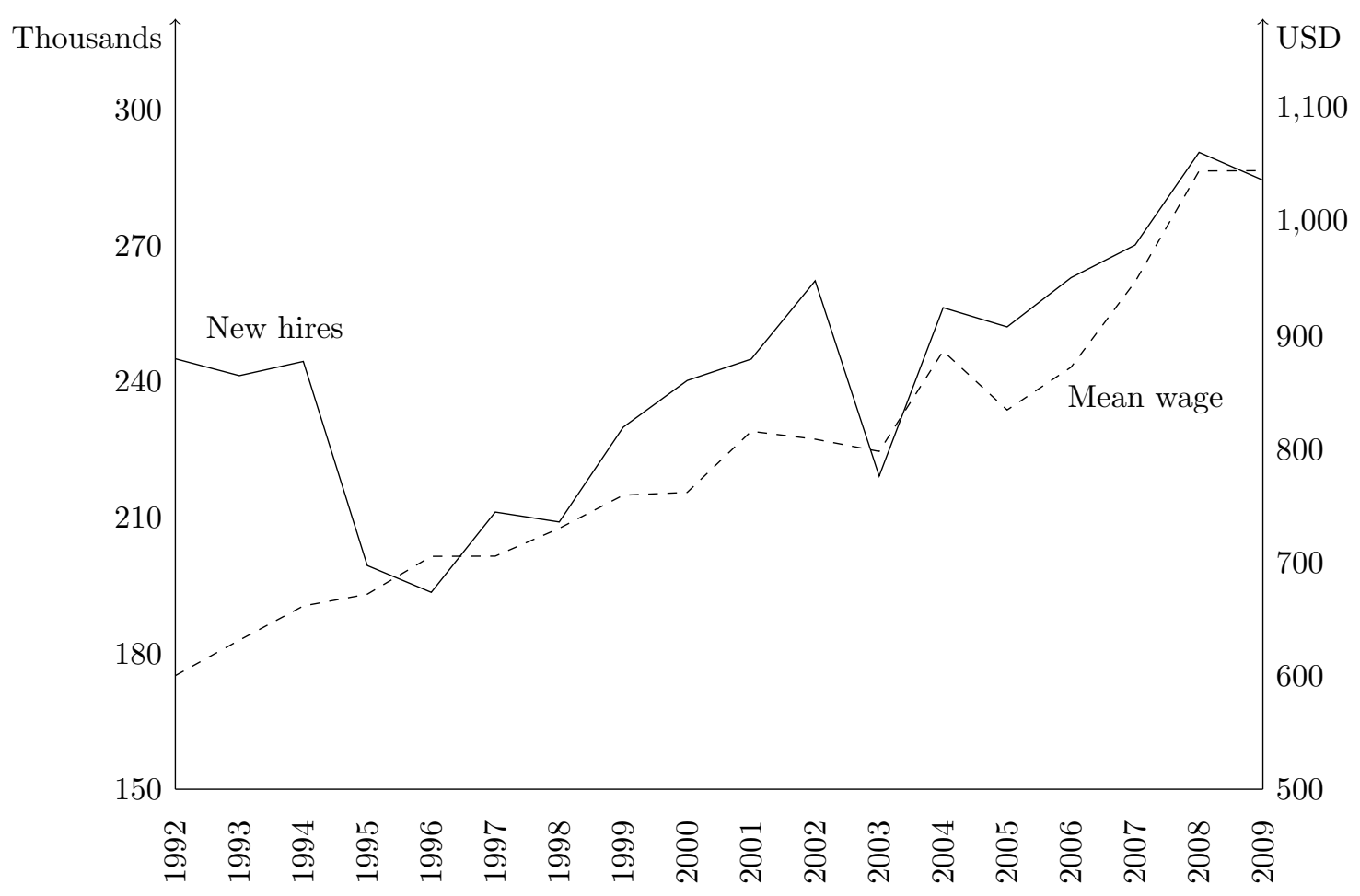

Note: total number of new hires (left axis) and mean wage (right axis) across the 54 destination countries included in the analysis.

Source: Authors' elaboration on the replication files from McKenzie et al. (2014).

193,453 new hires in 1996 and 290,545 in 2008. The mean wage increases from 600 USD in 1992 to 1,046 USD in 2009. Table 1 reports the number of total new hires over our period of analysis for each of the 54 countries in our sample. Saudi Arabia represents the main destination country, accounting for 30.02 percent of the total number of new hires over our period of analysis, followed by Japan, Taiwan and the United Arab Emirates, with each of these three countries representing more than 10 percent of the total number of new hires. ${ }^{17}$

\footnotetext{
${ }^{17}$ Japan introduced in 2005 new rules for the recruitment of temporary Filipino migrants, in response to allegations about the exploitation of female Filipino migrants, who had been "almost exclusively employed as overseas performing artists" (Theoharides, 2013, p. 26); these new rules led to a collapse in the number of new hires, which went down from 71,636 in 2004 to 7,107 in 2007, and then further declined to 1,882 in 2009.
} 
Table 1: New hires (1992-2009)

\begin{tabular}{|c|c|c|c|c|c|}
\hline Destination & Total & Share $^{a}$ & Destination & Total & Share $^{a}$ \\
\hline Saudi Arabia & 906,971 & 30.02 & Cuba & 2,303 & 0.08 \\
\hline Japan & 471,467 & 15.60 & New Zealand & 2,199 & 0.07 \\
\hline Taiwan & 419,551 & 13.89 & China & 2,173 & 0.07 \\
\hline United Arab Emirates & 357,851 & 11.84 & Yemen & 1,445 & 0.05 \\
\hline Hong Kong & 257,007 & 8.51 & Indonesia & 968 & 0.03 \\
\hline Kuwait & 194,337 & 6.43 & Micronesia & 957 & 0.03 \\
\hline South Korea & 48,023 & 1.59 & India & 796 & 0.03 \\
\hline Canada & 41,158 & 1.36 & Vietnam & 781 & 0.03 \\
\hline Singapore & 40,523 & 1.34 & Pakistan & 660 & 0.02 \\
\hline Bahrain & 40,018 & 1.32 & Thailand & 594 & 0.02 \\
\hline Brunei Darussalam & 28,197 & 0.93 & Ghana & 514 & 0.02 \\
\hline Israel & 27,840 & 0.92 & Norway & 492 & 0.02 \\
\hline United Kindgom & 25,649 & 0.85 & Netherlands & 490 & 0.02 \\
\hline United States & 25,541 & 0.85 & South Africa & 480 & 0.02 \\
\hline Oman & 20,077 & 0.66 & Greece & 417 & 0.01 \\
\hline Italy & 16,392 & 0.54 & Marshall Islands & 412 & 0.01 \\
\hline Malaysia & 15,275 & 0.51 & Switzerland & 298 & 0.01 \\
\hline Cyprus & 13,526 & 0.45 & Belgium & 296 & 0.01 \\
\hline Spain & 11,381 & 0.38 & Finland & 281 & 0.01 \\
\hline Jordan & 10,802 & 0.36 & Syria & 215 & 0.01 \\
\hline Australia & 7,910 & 0.26 & Sri Lanka & 207 & 0.01 \\
\hline Algeria & 5,808 & 0.19 & France & 194 & 0.01 \\
\hline Russia & 4,438 & 0.15 & Fiji & 181 & 0.01 \\
\hline Angola & 4,333 & 0.14 & Solomon Islands & 163 & 0.01 \\
\hline Papua New Guinea & 3,727 & 0.12 & Austria & 156 & 0.01 \\
\hline Sudan & 3,416 & 0.11 & Germany & 132 & 0.00 \\
\hline Palau & 2,415 & 0.08 & Sweden & 74 & 0.00 \\
\hline
\end{tabular}

The POEA also provides estimates of the stock of temporary Filipino workers and of the total number of Filipinos residing in each destination in December 2009, at the end of our period of analysis. The data reveal that temporary migration represents the main -at times, nearly the unique- entry door for Filipino migrants in a number of destination countries: for instance, 98.2 percent of Filipinos residing in Saudi Arabia in December 2009 were temporary migrants, and the median share of temporary migrants over our sample of 
destination countries stands at 69.3 percent. ${ }^{18,19}$

The geographically diverse set of destination countries in our sample clearly experienced a different evolution in their macroeconomic conditions over our period of analysis, but it is important to observe that business cycle conditions of destination countries located in the same region display a remarkable degree of (positive) correlation, which might pose a threat to identification, as discussed in Section 2. For instance, Figure 4 plots the evolution of real GDP growth between 1993 and 2009 for South Korea and Malaysia, to give a visual feeling of the extent of the correlation in the evolution of macroeconomic conditions in relevant destinations for Filipino migrants.

Figure 4: Real GDP growth rates for Malaysia and South Korea, 1993-2009

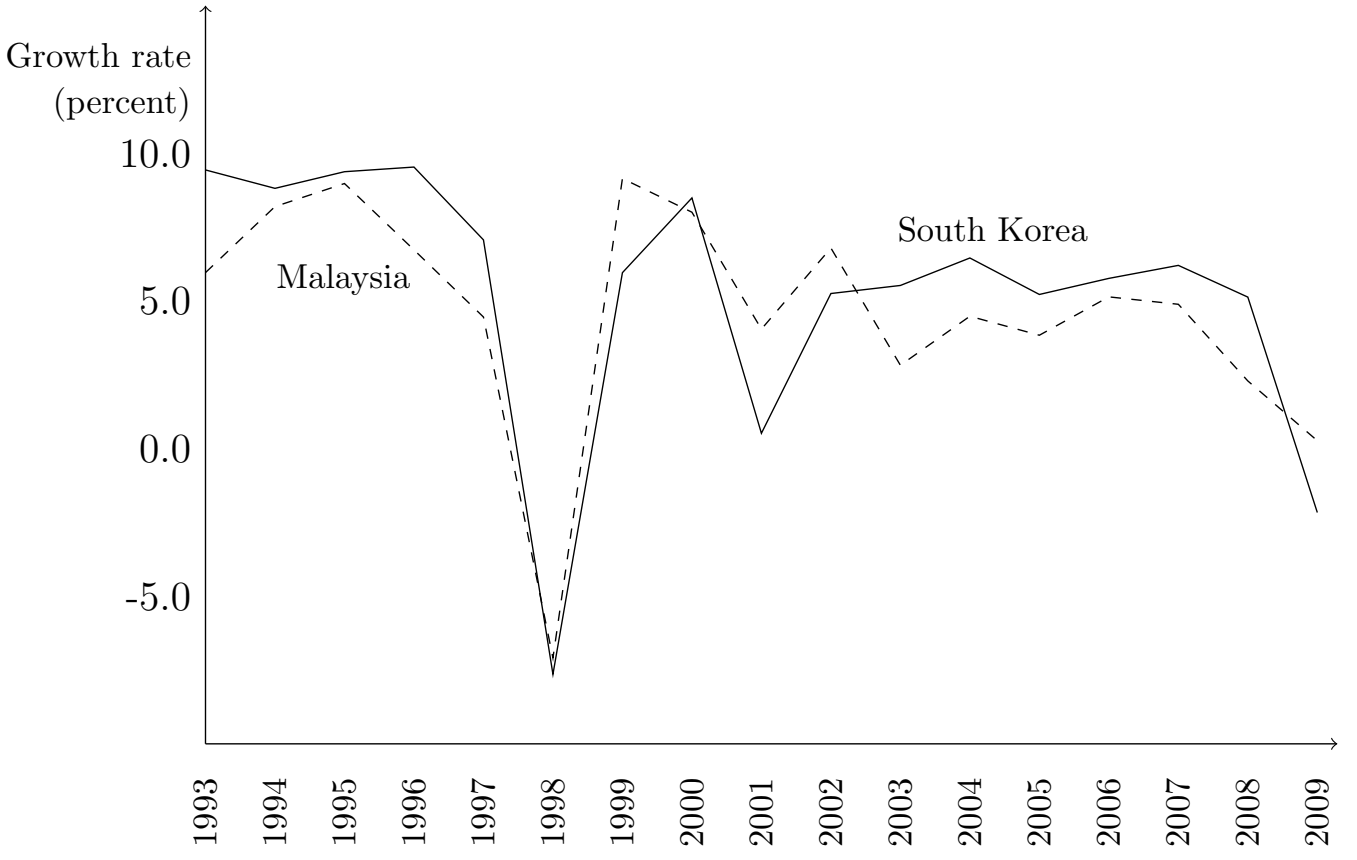

Source: Authors' elaboration on World Bank (2015).

Overall, the average correlation of GDP growth across the 54 countries in the sample is actually 0.24 but this goes up to 0.41 when we confine ourselves to the ten main destinations

\footnotetext{
${ }^{18}$ Authors' elaboration on POEA, Stock estimates of Filipinos Overseas (Inter-Agency Report), available at: http://www.poea.gov.ph/stats/statistics.html (last accessed on June, 25, 2015).

${ }^{19}$ Other channels of entry, such as family reunification provisions, appear to dominate in some OECD destinations-such as Canada, the United States or Australia, where temporary migrants only represent a limited fraction of the total stock of Filipino immigrants.
} 
(see Table 1), and even to 0.75 if we concentrate on the six East Asian countries, namely Japan, Taiwan, Hong Kong, South Korea, Singapore and Malaysia, which account for more than 40 percent of new hires. ${ }^{20}$ This implies that the concern about the threat to identification posed by correlated variations in macroeconomic conditions across destinations has a strong empirical relevance in this case.

\section{Econometric analysis}

We present here the results from the estimation of the restricted and unrestricted versions of the wage and of the migration equations, and the ensuing values for the elasticity of the migrant labor supply. ${ }^{21}$ All our results are robust when we rely on median rather than mean wages as the dependent variable in the wage equation, and when we estimate the wage equation separately on the sub-sample of male and female Filipino migrants; the Appendix A.2 reports these additional specifications. ${ }^{22} 23$

\subsection{Reduced form wage equation}

Table 2 presents three different ways of estimating the relationship between mean wages of overseas Filipino workers and contemporaneous GDP shocks. ${ }^{24}$ In Column (1), we present the estimate of the restricted version of (5), i.e., we estimate (2), and we assign an equal weight to each observation. The elasticity of the mean wage with respect to GDP per capita is statistically zero in an unweighted estimation with destination and year fixed effects. However, things change drastically in Column (2), where we weight the observations corresponding to each destination-year by the corresponding total number $m_{j t}$ of overseas

\footnotetext{
${ }^{20}$ Similarly, the average pairwise correlation of real GDP growth across the 15 European countries in Table 1 stands at 0.73 .

${ }^{21}$ The restricted versions of the wage and of the migration equations assume that all destination countries are equally substitutable for potential migrants, while the unrestricted versions allow for different patterns of substitution across destinations for potential migrants (see Section 2.4).

${ }^{22}$ We also present in the Appendix A.2 the regressions run on a sample that excludes Japan, given the collapse in the number of (mostly female) new hires to this destination after 2005 that was induced by the change in recruitment policies (Theoharides, 2015).

${ }^{23}$ The estimates are also robust to the exclusion of the main destination (Saudi Arabia) from the sample; results are available from the authors upon request.

${ }^{24}$ Wage data are missing for 5 out of 972 observations.
} 
Filipino workers. This practice is common in the migration literature (see, for instance, Borjas, 2003 and Mishra, 2007), and it prevents results from being driven by observations with a limited number of migrants, where measurement error in migrants' wages might be a severe concern. ${ }^{25}$ Once we weight the observations, the elasticity of mean wages with respect to GDP shocks is estimated at 0.46 , and it is significant at the 5 percent confidence level. ${ }^{26}$

Table 2: Migrants' wage regressions

\begin{tabular}{lc|cc}
\multicolumn{4}{c}{ Dependent variable: $\ln ($ mean wages $)$} \\
Specification & $(1)$ & $(2)$ & $(3)$ \\
Variables & -0.04 & $0.46^{* *}$ & $0.39^{* * *}$ \\
\hline Log GDP & {$[0.14]$} & {$[0.18]$} & {$[0.04]$} \\
& & & \\
& 967 & 967 & 967 \\
Observations & 0.74 & 0.97 & 0.98 \\
Adjusted $R^{2}$ & Yes & Yes & Yes \\
Country dummies & Yes & Yes & Yes \\
Year dummies & No & Yes & Yes \\
Weights & & \multicolumn{2}{|c}{$4.13^{* * *}$} \\
\hline$H_{0}:(2)$ nested in $(3)^{a} ; F$-test & & \multicolumn{2}{|c}{$(0.00)$} \\
$(p$-value $)$ & & \multicolumn{2}{|c}{0.10} \\
$H_{0}: \widehat{\psi}_{w}^{(2)}=\widehat{\psi}_{w}^{(3)} ; C h i^{2}$ test & & \multicolumn{2}{|c}{$(0.75)$} \\
$(p$-value $)$ & &
\end{tabular}

Notes: ${ }^{* * *} p<0.01,{ }^{* *} p<0.05,{ }^{*} p<0.10$; standard errors clustered at the country level in brackets for specifications (1) and (2); specification (1) corresponds to Table 2, Panel A in McKenzie et al. (2014); observations in specifications (2) and (3) are weighted by $m_{j t} ;{ }^{a}(2)$ and (3) refer to the specification in the table. The restricted version of the estimation equation assumes that all destination countries are equally substitutable for potential migrants. The unrestricted version allows for different patterns of substitution across destinations for potential migrants.

Source: Authors' elaboration on the replication data from McKenzie et al. (2014).

\footnotetext{
${ }^{25}$ Weighting also allows us to recover the estimates that we would have obtained running the model on micro instead of on aggregate data (Angrist and Pischke, 2009).

${ }^{26}$ In addition, the explanatory power of the model increases substantially: the adjusted $R^{2}$ goes up from 0.74 to 0.97 in Table 2 .
} 
Column (3) presents the results of estimating the unrestricted version of version of (5). The $F$-test, which is conducted on the null hypothesis that $\phi_{w j}=\phi_{w}$, reveals that the coefficients of the auxiliary regressors added by the CCE procedure vary across destinations, thus validating the need to lift the restriction upon which the estimation of (2) reported in Column (2) is based. The estimated elasticity in Column (3), which is significant at the 1 percent confidence level, is very similar in magnitude to the one observed in Column (2). The elasticity decreases, as predicted by the theory in the empirically relevant scenario of a predominantly positive correlation in macroeconomic conditions across destinations, but only from 0.46 to 0.39 , an insignificant difference at conventional levels. This result suggests that labor demand is elastic enough so that substitutability patterns across destinations do not affect migrant wages much.

\subsection{Reduced form migration equation}

Table 3 presents two alternative estimations for equation (4), which give us an estimate of the elasticity of the number of new hires of overseas Filipino workers with respect to real GDP at destination. Column (1) contains the results from the estimation of the restricted version of (4), i.e., (1). The estimated coefficient on log GDP implies an elasticity of 1.52 in the relationship between GDP shocks and number of overseas Filipino workers. ${ }^{27}$

Column (2) shows the results of running the unrestricted version of the same equation, thus allowing for a richer structure of the error term that allows for different substitution patterns across destinations for migrants by using the CCE estimator. The test on the significance of the destination-specific auxiliary regressors added by the CCE estimator confirms the need to control for a richer substitution pattern across destinations and the test for the equality of coefficients between both models rejects the null at a 5 percent significance level $(p$-value $=0.03)$, despite the large clustered standard errors implied by the base specification. This suggests the need for a more complicated structure of the error term in equation (1) that cannot be controlled for just by adding destination and year fixed effects.

\footnotetext{
${ }^{27}$ This and subsequent elasticities on migration regressions should be interpreted as an upper bound on the true elasticity in a RUM-based model (Bertoli and Fernández-Huertas Moraga, 2015).
} 
Table 3: Migration regression

\begin{tabular}{|c|c|c|}
\hline \multicolumn{3}{|c|}{ Dependent variable: $\ln \left(m_{j t}\right)$} \\
\hline Specification & Restricted & Unrestricted \\
\hline Variables & $(1)$ & $(2)$ \\
\hline \multirow[t]{2}{*}{ Log GDP } & $1.52^{* * *}$ & $3.38^{* * *}$ \\
\hline & {$[0.50]$} & {$[0.67]$} \\
\hline Observations & 972 & 972 \\
\hline Adjusted $R^{2}$ & 0.85 & 0.90 \\
\hline Country dummies & Yes & Yes \\
\hline Year dummies & Yes & Yes \\
\hline \multirow{2}{*}{$\begin{array}{l}H_{0}:(1) \text { nested in }(2)^{a} ; F \text {-test } \\
(p \text {-value })\end{array}$} & \multicolumn{2}{|c|}{$4.93 * * *$} \\
\hline & \multicolumn{2}{|c|}{$(0.00)$} \\
\hline$H_{0}: \widehat{\psi}_{m}^{(1)}=\widehat{\psi}_{m}^{(2)} ; C h i^{2}$ test & \multicolumn{2}{|c|}{$4.51^{* *}$} \\
\hline$(p$-value $)$ & \multicolumn{2}{|c|}{$(0.03)$} \\
\hline \multicolumn{3}{|c|}{$\begin{array}{l}\text { Notes: }{ }^{* *} p<0.01,{ }^{* *} p<0.05, * p<0.10 \text {; standard } \\
\text { errors clustered at the country level in brackets for specifi- } \\
\text { cation (1); specification (1) corresponds to Table } 2 \text {, Panel }\end{array}$} \\
\hline \multirow{5}{*}{\multicolumn{3}{|c|}{$\begin{array}{l}\text { A in McKenzie et al. }(2014) ;^{a}(1) \text { and }(2) \text { refer to the } \\
\text { specification in the table. The restricted version of the es- } \\
\text { timation equation assumes that all destination countries } \\
\text { are equally substitutable for potential migrants. The unre- } \\
\text { stricted version allows for different patterns of substitution } \\
\text { across destinations for potential migrants. }\end{array}$}} \\
\hline & & \\
\hline & & \\
\hline & & \\
\hline & & \\
\hline \multicolumn{3}{|c|}{ Source: Authors' elaboration on the replication data from } \\
\hline McKenzie et al. (2014). & & \\
\hline
\end{tabular}

The estimated coefficient for GDP increases from 1.52 to 3.38. The elasticity estimated in Column (1) is downward biased, as expected with a positive correlation in the evolution of macroeconomic conditions across destinations (see Section 3), the case depicted in Figure 2. The intuition for the difference is straightforward. For each destination and year, the 1.52 coefficient was picking up both the direct positive effect of GDP shocks on migration to that destination and that year and the indirect negative effect of correlated shocks in alternative destinations or in the same destination in different years. 


\subsection{The implied elasticity of the migrant labor supply}

The tests conducted on the estimates of the reduced form wage and migration equations presented in Tables 2 and 3 reject the restrictions upon which equations (2) and (1) are based. Thus, the unrestricted versions of the two reduced form equations-with weights included in the wage equation-represent our preferred specifications. When we take the ratio between $\widehat{\psi}_{m}=3.38$ from Column (2) of Table 3 and $\widehat{\psi}_{w}=0.39$ from Column (2) of

Table 2 , we obtain an implied labor supply elasticity $\widehat{\beta}$ of temporary Filipino migrants which stands at $8.57($ s.e. $=2.91){ }^{28}$

As the estimation of the restricted versions of the two equations deliver a downward biased estimate of $\psi_{m}$ and an upward biased $\psi_{w}$, following the prediction of our simple theoretical model, then they result in a significant underestimation of $\beta$, which stands at $3.34($ s.e. $=1.50)$. Dealing with the threats to identification in the reduced form regressions proves to be crucial for a sound measurement of the elasticity of migrant labor supply.

\section{Concluding remarks}

The reaction of international migrants to wage differences across countries depends on the interaction of the labor supply decisions of the workers and the labor demand situation in every potential destination. This simple observation has implications on how we should interpret the reduced form estimates from gravity models of international migration. In particular, gravity equation parameters on economic conditions are not equivalent to labor supply elasticities.

In this paper, we explicitly show the relationship between the estimates from a gravity model of migration and the labor supply elasticity. We then go on to provide an example by estimating an upper bound on the elasticity of the labor supply of temporary Filipino migrant workers between 1992 and 2009. We find that the labor supply elasticity of this subset of workers is as high as 8.57 , which implies that temporary Filipino migrants are very responsive to wages offered by employers at different destinations. Summing up, they retain a very high ability to choose among competing offers by changing their destination.

From the point of view of host countries, this high responsiveness means that laborimporting countries should not take temporary workers for granted. They will not be willing

\footnotetext{
${ }^{28}$ Bootstrapped standard errors from resampling 100 times with replacement.
} 
to come if conditions become too harsh. A different issue, for future research, is the ability of host countries to substitute unwilling Filipino workers with workers from other origins. It would be interesting to understand whether the high labor supply elasticity of Filipino migrants is matched by other countries of origin for temporary workers.

\section{References}

Angrist, J. D. And J.-S. Pischke (2009): Mostly Harmless Econometrics: An Empiricist's Companion, Princeton: Princeton University Press.

BAI, J. (2009): "Panel data models with interactive fixed effects," Econometrica, 77, 12291279 .

Beine, M., S. Bertoli, and J. Fernández-Huertas Moraga (2016): "A practitioners' guide to gravity models of international migration," The World Economy, 39, 596-612.

Bertoli, S., and J. Fernández-Huertas Moraga (2013): "Multilateral Resistance to Migration," Journal of Development Economics, 102, 79-100.

Bertoli, S., and J. Fernández-Huertas Moraga (2015): "The size of the cliff at the border," Regional Science and Urban Economics, 51, 1-6.

Borjas, G. J. (2003): "The Labor Demand Curve Is Downward Sloping: Reexamining the Impact of Immigration on the Labor Market," Quarterly Journal of Economics, 118, 1335-1374.

Borjas, G. J., J. Grogger and G. H. Hanson (2012): "Comment: on Estimating Elasticities of Substitution," Journal of the European Economic Association, 10(1), 198223.

Chetty, R., A. Guren, D. S. Manoli and A. Weber (2015): "Does Indivisible Labor Explain the Difference between Micro and Macro Elasticities? A Meta-Analysis of Extensive Margin Elasticities," Macroeconomics Annual 2012, University of Chicago Press, $27(1), 1-56$.

Cortes, P. (2015): "The Feminization of International Migration and its Effects on the Children Left Behind: Evidence from the Philippines," World Development, 65, 62-78. 
Driscoll, J. C., And A. C. KraAy (1998): "Consistent Covariance Matrix Estimation with Spatially Dependent Panel Data," Review of Economics and Statistics, 80, 549-560.

Kleven, H. J, C. Landais, E. Saez and E. Schultz (2014): "Migration and Wage Effects of Taxing Top Earners: Evidence from the Foreigners' Tax Scheme in Denmark," Quarterly Journal of Economics, 129(1), 333-378.

Licuanan, V., T. Omar Mahmoud, and A. Steinmayr (2015): "The Drivers of Diaspora Donations for Development: Evidence from the Philippines," World Development, 65, 94-109.

MaCurdy, T., D. Green, and H. PaArsch (1990): "Assessing Empirical Approaches for Analyzing Taxes and Labor Supply," Journal of Human Resources, 25, 415-490.

McFadden, D. (1974): "Conditional logit analysis of qualitative choice behavior," in Frontiers in Econometrics, ed. by P. Zarembka, pp. 105-142. New York: Academic Press.

McKenzie, D., C. Theoharides, and D. Yang (2014): "Distortions in the International Migrant Labor Market: Evidence from Filipino Migration and Wage Responses to Destination Country Economic Shocks," American Economic Journal: Applied Economics, $6(2), 49-75$.

Milanovic, B. (2005): Global and International Inequality 1950-2000, Princeton: Princeton University Press.

Milanovic, B. (2015): "Global Inequality of Opportunity: How Much of Our Income Is Determined by Where We Live?," Review of Economics and Statistics, 97, 452-460.

Mishra, P. (2007): "Emigration and wages in source countries: Evidence from Mexico," Journal of Development Economics, 82(1), 180-199.

Ortega, F., and G. Peri (2013): "The Role of Income and Immigration Policies in Attracting International Migrants," Migration Studies, 1(1), 47-74.

Ottaviano, G. I. P., and G. Peri (2012): "Rethinking the Effect of Immigration of Wages," Journal of the European Economic Association, 10(1), 152-197. 
Pesaran, M. H. (2006): "Estimation and Inference in Large Heterogeneous Panels with a Multifactor Error Structure," Econometrica, 74, 967-1012.

Pesaran, M. H. and E. Tosetti (2011): "Large Panels with Common Factors and Spatial Correlation," Journal of Econometrics, 161(2), 182-202.

Pritchett, L. (2006): Let Their People Come. Washington: Center for Global Development.

Rider, P. R. (1960): "Variance of the Median of Small Samples from Several Special Populations," Journal of the American Statistical Association, 55(289), 148-150.

Small, K. A., And H. S. Rosen (1981): "Applied Welfare Economics with Discrete Choice Models," Econometrica, 49(1), 105-130.

Theoharides, C. (2013): "Manila to Malaysia, Quezon to Qatar: International Migration and the Effects of Origin-Country Human Capital," mimeo, Ann Arbor: University of Michigan.

Theoharides, C. (2015): "Banned from the Band: The Effect of Migration Barriers on Origin-Country Labor Market Decisions," paper presented at the Eight Migration and Development Conference, June 2015, Washington.

World BANK (2015): World Development Indicators, Washington: The World Bank.

YAnG, D. (2006): "Why Do Migrants Return to Poor Countries? Evidence from Philippine Migrants' Responses to Exchange Rate Shocks," Review of Economics and Statistics, 88, $715-735$.

YANG, D. (2008): "International Migration, Remittances and Household Investment: Evidence from Philippine Migrants' Exchange Rate Shocks," Economic Journal, 118, 591-630. 


\section{A Appendix}

This appendix provides details on the model and the estimation equations discussed in the paper, as well as supplemental tables referenced in the main text.

\section{A.1 The market for temporary migrant labor}

Let $m_{j t}$ represent the number of migrants that move on a temporary basis from an origin country to the destination country $j=1, \ldots, N$ at time $t=1, \ldots, T$, and let $\mathbf{w}_{t}=$ $\left(w_{0 t}, w_{1 t}, \ldots, w_{N t}\right)^{\prime}$ and $\mathbf{c}_{t}=\left(c_{0 t}, c_{1 t}, \ldots, c_{N t}\right)^{\prime}$ be two vectors that gather migrants' wages and bilateral migration costs and time $t .{ }^{29}$ The inverse demand function for temporary migrant labor is given by:

$$
w_{j t}=a_{j} y_{j t}^{\alpha} m_{j t}^{-\phi}
$$

where $y_{j t}$ is the real GDP in country $j$ at time $t$, and $a_{j}$ is a time-invariant parameter that shifts the inverse labor demand in destination $j$. The supply of migrant labor can be derived from an underlying static random utility maximization model that describes the location-decision problem that potential migrants face, which represents the standard micro-foundation of a gravity equation for migration (Beine et al., 2016). Specifically, if the deterministic component of utility $V_{j t}$ depends on the logarithm of the wage $w_{j t}$ and on bilateral migration $\operatorname{costs} c_{j t}$, i.e., $V_{j t}=\beta \ln \left(w_{j t}\right)-c_{j t}$, then the distributional assumptions in McFadden (1974) on the individual-specific stochastic component $\epsilon_{i j t}$ allow to write the expected value of the labor supply $m_{j t}$ as follows: ${ }^{30}$

$$
E\left(m_{j t}\right)=w_{j t}^{\beta} e^{-c_{j t}-\Omega\left(\mathbf{w}_{t}, \mathbf{c}_{t}\right)} n_{t}
$$

where $n_{t}$ is the size of the population at origin, and:

$$
\Omega\left(\mathbf{w}_{t}, \mathbf{c}_{t}\right)=\ln \left(\sum_{k=0}^{N} w_{k t}^{\beta} e^{-c_{k t}}\right)
$$

represents the expected value from the choice situation that potential migrants face at time $t$ (Small and Rosen, 1981). The function $\Omega\left(\mathbf{w}_{t}, \mathbf{c}_{t}\right)$ in (A.2), which describes the influence

\footnotetext{
${ }^{29} \mathrm{We}$ let $w_{0 t}$ denote the wage in the origin country at time $t$, and we normalize the cost of staying $c_{0 t}$ to zero.

${ }^{30}$ We thus assume that $\epsilon_{i j t}$ follows an independent and identically distributed Extreme Value Type-1 distribution.
} 
exerted by the attractiveness of all countries on the expected value of the migrant labor supply to destination $j$ at time $t$, varies over time but it is invariant across destinations.

\section{A.1.1 The elasticity of the labor supply}

We can recover the elasticity of the migrant labor supply from (A.2) assuming, by the law of large numbers, that $E\left(m_{j t}\right)=m_{j t}$. We have that:

$$
\frac{\partial \ln \left(m_{j t}\right)}{\partial \ln \left(w_{j t}\right)}=\beta\left(1-p_{j t}\right)
$$

The elasticity in (A.3) depends on the actual migration rate $p_{j t} \equiv m_{j t} / n_{t}$ between the origin and each destination at time $t$. In practice, $p_{j t}$ will be very small for any $j=1, \ldots, N$ and any $t=1, \ldots, T$ since only a tiny fraction of the Filipino population migrates to a single destination in a given year, so that $\beta\left(1-p_{j t}\right) \approx \beta$, and we will be referring to $\beta$ as the labor supply elasticity, even though formally it is just an upper bound of the true elasticity.

We can rearrange the terms in (A.1) and (A.2) to obtain (a logarithmic transformation of) the inverse demand function $D_{j}\left(y_{j t}\right)$ and the inverse supply function $S_{j}\left(\mathbf{w}_{t}, \mathbf{c}_{t}\right)$ for migrant labor in destination $j$, as:

$$
D\left(y_{j t}\right)=\ln \left(a_{j}\right)+\alpha \ln \left(y_{j t}\right)-\phi \ln \left(m_{j t}\right)
$$

and:

$$
S_{j}\left(\mathbf{w}_{t}, \mathbf{c}_{t}\right)=\beta^{-1}\left[\ln \left(m_{j t}\right)+c_{j t}+\Omega\left(\mathbf{w}_{t}, \mathbf{c}_{t}\right)-\ln \left(n_{t}\right)\right],
$$

We can observe from (A.5) that $S_{k}\left(\mathbf{w}_{t}, \mathbf{c}_{t}\right)=S_{j}\left(\mathbf{w}_{t}, \mathbf{c}_{t}\right)+\beta^{-1}\left(c_{k t}-c_{j t}\right)$, i.e., the inverse supply functions for two destinations differ only by a term which is proportional to the difference in the bilateral migration costs.

\section{A.1.2 Reduced form regressions}

We can derive the following reduced-form regression that gives us the elasticity of the scale of migration with respect to the real GDP at destination combining (A.1) and (A.2) with $E\left(m_{j t}\right)=m_{j t}$ :

$$
\ln \left(m_{j t}\right)=\frac{\alpha \beta}{1+\phi \beta} \ln \left(y_{j t}\right)-\frac{1}{1+\phi \beta}\left[\Omega\left(\mathbf{w}_{t}, \mathbf{c}_{t}\right)+c_{j t}-\ln \left(n_{t}\right)\right]+\frac{\beta}{1+\phi \beta} \ln \left(a_{j}\right)+\varepsilon_{j t}^{m} .
$$


Similarly, the reduced-form regression that gives us the elasticity of migrants' wages with respect to the real GDP at destination can be written as:

$$
\ln \left(w_{j t}\right)=\frac{\alpha}{1+\phi \beta} \ln \left(y_{j t}\right)+\frac{\phi}{1+\phi \beta}\left[\Omega\left(\mathbf{w}_{t}, \mathbf{c}_{t}\right)+c_{j t}-\ln \left(n_{t}\right)\right]+\frac{1}{1+\phi \beta} \ln \left(a_{j}\right)+\varepsilon_{j t}^{w} .
$$

Under the assumption that the bilateral migration costs can have different levels across destinations but follow an identical time profile, ${ }^{31}$ then the two elasticities of interest can be identified through the estimation of the following two equations:

$$
\ln \left(m_{j t}\right)=\psi_{m} \ln \left(y_{j t}\right)+\boldsymbol{\beta}_{m}{ }^{\prime} \mathbf{d}_{j}+\boldsymbol{\gamma}_{m}{ }^{\prime} \mathbf{d}_{t}+\varepsilon_{j t}^{m}
$$

and:

$$
\ln \left(w_{j t}\right)=\psi_{w} \ln \left(y_{j t}\right)+\boldsymbol{\beta}_{w}{ }^{\prime} \mathbf{d}_{j}+\boldsymbol{\gamma}_{w}{ }^{\prime} \mathbf{d}_{t}+\varepsilon_{j t}^{w},
$$

where $w_{j t}$ in (A.9) is either the mean or the median wage earned by the $m_{j t}$ migrants and $\mathbf{d}_{j}$ and $\mathbf{d}_{t}$ are two vectors of destination and time dummies. Destination dummies $\mathbf{d}_{j}$ control for the dyadic time-invariant component $c_{j}$ of migration costs, and for the term $\ln \left(a_{j}\right)$ in (A.4) that influences the level of the demand for temporary migrant labor. Time dummies $\mathbf{d}_{t}$ control for the factors that exert a time-varying influence on $\ln \left(m_{j t}\right)$ and $\ln \left(w_{j t}\right)$ for any $j=1, \ldots, N$, such as demographic factors at origin or variations in macroeconomic conditions in all potential destinations and at origin.

It is then immediate from (A.6)-(A.9) to recover an estimate of the labor supply elasticity parameter $\beta$ in (A.3) as:

$$
\widehat{\beta}=\frac{\widehat{\psi}_{m}}{\widehat{\psi}_{w}}
$$

\footnotetext{
${ }^{31}$ Formally, we assume that $c_{j t}=c_{j}+f_{t}$ for all $j \in D$; this assumption implies that the difference between $S_{k}\left(\mathbf{w}_{t}, \mathbf{c}_{t}\right)$ and $S_{j}\left(\mathbf{w}_{t}, \mathbf{c}_{t}\right)$, with $j, k \in D$, is time-invariant.
} 


\section{A.2 Additional specifications}

Table A.1: Median wages

\begin{tabular}{lc|cc}
\multicolumn{3}{c}{$\begin{array}{c}\text { Dependent variable: } \\
\ln (\text { median wages })\end{array}$} \\
Specification & $\begin{array}{c}\text { Restricted } \\
\text { Variables }\end{array}$ & Restricted & Unrestricted \\
\hline Log GDP & -0.06 & $0.61^{* *}$ & $0.78^{* * *}$ \\
& {$[0.16]$} & {$[0.23]$} & {$[0.05]$} \\
& & & \\
Observations & 967 & 967 & 967 \\
Adjusted $R^{2}$ & 0.72 & 0.96 & 0.98 \\
Country dummies & Yes & Yes & Yes \\
Year dummies & Yes & Yes & Yes \\
Weights & No & Yes & Yes \\
\hline$H_{0}:(2)$ nested in $(3)^{a} ; F$-test & & \multicolumn{2}{|c}{$5.73^{* * *}$} \\
$(p$-value $)$ & & \multicolumn{2}{|c}{$(0.00)$} \\
Test, $H_{0}: \widehat{\psi}_{w}^{(2)}=\widehat{\psi}_{w}^{(3)} ; C h i^{2}$ test & & \multicolumn{2}{|c}{0.49} \\
$(p$-value $)$ & & \multicolumn{2}{|c}{$(0.48)$}
\end{tabular}

Notes: ${ }^{* * *} p<0.01,{ }^{* *} p<0.05,{ }^{*} p<0.10$; standard errors clustered at the country level in brackets for specifications (1) and (2); specification (1) corresponds to Table 2, Panel A in McKenzie et al. (2014); observations in specifications (2) and (3) are weighted by $m_{j t} ;{ }^{a}(2)$ and (3) refer to the specification in the table. The restricted version of the estimation equation assumes that all destination countries are equally substitutable for potential migrants. The unrestricted version allows for different patterns of substitution across destinations for potential migrants.

Source: Authors' elaboration on the replication data from McKenzie et al. (2014). 
Table A.2: Mean wages by gender

Dependent variable:

\begin{tabular}{|c|c|c|c|}
\hline \multicolumn{4}{|c|}{$\ln ($ mean wages $)$} \\
\hline $\begin{array}{l}\text { Specification } \\
\text { Variables }\end{array}$ & $\begin{array}{l}\text { Restricted } \\
\quad(1)\end{array}$ & $\begin{array}{l}\text { Restricted } \\
\quad(2)\end{array}$ & $\begin{array}{c}\text { Unrestricted } \\
(3)\end{array}$ \\
\hline \multicolumn{4}{|l|}{ Panel A: Male sample } \\
\hline \multirow[t]{2}{*}{ Log GDP } & -0.03 & $0.46^{* * *}$ & $0.33^{* * *}$ \\
\hline & {$[0.12]$} & {$[0.13]$} & {$[0.09]$} \\
\hline $\begin{array}{l}H_{0}:(2) \text { nested in }(3)^{a} ; F \text {-test } \\
(p \text {-value })\end{array}$ & & \multicolumn{2}{|c|}{$8.47^{* * *}$} \\
\hline$H_{0}: \widehat{\psi}_{m}^{(2)}=\widehat{\psi}_{m}^{(3)} ; C h i^{2}$ test & & \multicolumn{2}{|c|}{0.64} \\
\hline$(p$-value $)$ & & \multicolumn{2}{|c|}{$(0.42)$} \\
\hline Observations & 930 & 930 & 930 \\
\hline Adjusted $R^{2}$ & 0.67 & 0.92 & 0.96 \\
\hline \multicolumn{4}{|l|}{ Panel B: Female sample } \\
\hline \multirow[t]{2}{*}{ Log GDP } & 0.04 & $0.46^{* * *}$ & $0.34^{* * *}$ \\
\hline & {$[0.21]$} & {$[0.16]$} & {$[0.05]$} \\
\hline $\begin{array}{l}H_{0}:(2) \text { nested in }(3)^{a} ; F \text {-test } \\
(p \text {-value })\end{array}$ & & \multicolumn{2}{|c|}{$4.89 * * *$} \\
\hline $\begin{array}{l}H_{0}: \widehat{\psi}_{w}^{(2)}=\widehat{\psi}_{w}^{(3)} ; C h i^{2} \text { test } \\
(p \text {-value) }\end{array}$ & & \multicolumn{2}{|c|}{$\begin{array}{c}0.46 \\
(0.50)\end{array}$} \\
\hline Observations & 901 & 901 & 901 \\
\hline Adjusted $R^{2}$ & 0.75 & 0.98 & 0.98 \\
\hline Country dummies & Yes & Yes & Yes \\
\hline Year dummies & Yes & Yes & Yes \\
\hline Weights & No & Yes & Yes \\
\hline
\end{tabular}

Notes: ${ }^{* * *} p<0.01,{ }^{* *} p<0.05,{ }^{*} p<0.10$; standard errors clustered at the country level in brackets for specifications (1) and (2); specification (1) corresponds to Table 2, Panel B and C in McKenzie et al. (2014); observations in specifications (2) and (3) are weighted by the gender-specific number of migrants $m_{j t} ;{ }^{a}(2)$ and (3) refer to the specification in the table. The restricted version of the estimation equation assumes that all destination countries are equally substitutable for potential migrants. The unrestricted version allows for different patterns of substitution across destinations for potential migrants. Source: Authors' elaboration on the replication data from McKenzie et al. (2014). 
Table A.3: Median wages by gender

Dependent variable:

$\ln$ (median wages)

\begin{tabular}{|c|c|c|c|}
\hline \multicolumn{4}{|c|}{$\ln ($ median wages $)$} \\
\hline Specification & Restricted & Restricted & Unrestricted \\
\hline Variables & $(1)$ & $(2)$ & $(3)$ \\
\hline \multicolumn{4}{|l|}{ Panel A: Male sample } \\
\hline \multirow[t]{2}{*}{ Log GDP } & -0.02 & $0.45^{* *}$ & $0.19^{*}$ \\
\hline & {$[0.15]$} & {$[0.18]$} & {$[0.10]$} \\
\hline$H_{0}:(2)$ nested in $(3)^{a} ; F$-test & & \multicolumn{2}{|c|}{$8.93^{* * *}$} \\
\hline$(p$-value $)$ & & \multicolumn{2}{|c|}{$(0.00)$} \\
\hline$H_{0}: \widehat{\psi}_{m}^{(2)}=\widehat{\psi}_{m}^{(3)} ; C h i^{2}$ test & & \multirow{2}{*}{\multicolumn{2}{|c|}{$\begin{array}{c}1.66 \\
(0.20)\end{array}$}} \\
\hline ( $p$-value) & & & \\
\hline Observations & 930 & 930 & 930 \\
\hline Adjusted $R^{2}$ & 0.65 & 0.89 & 0.95 \\
\hline \multicolumn{4}{|l|}{ Panel B: Female sample } \\
\hline \multirow[t]{2}{*}{ Log GDP } & -0.05 & $0.51^{* * *}$ & $0.35^{* * *}$ \\
\hline & {$[0.23]$} & {$[0.18]$} & {$[0.06]$} \\
\hline$H_{0}:(2)$ nested in $(3)^{a} ; F$-test & & \multirow{2}{*}{\multicolumn{2}{|c|}{$\begin{array}{c}4.29^{* * *} \\
(0.00)\end{array}$}} \\
\hline$(p$-value $)$ & & & \\
\hline$H_{0}: \widehat{\psi}_{w}^{(2)}=\widehat{\psi}_{w}^{(3)} ; C h i^{2}$ test & & \multirow{2}{*}{\multicolumn{2}{|c|}{$\begin{array}{c}0.58 \\
(0.45)\end{array}$}} \\
\hline ( $p$-value $)$ & & & \\
\hline Observations & 901 & 901 & 901 \\
\hline Adjusted $R^{2}$ & 0.74 & 0.97 & 0.98 \\
\hline Country dummies & Yes & Yes & Yes \\
\hline Year dummies & Yes & Yes & Yes \\
\hline Weights & No & Yes & Yes \\
\hline
\end{tabular}

Notes: ${ }^{* * *} p<0.01,{ }^{* *} p<0.05,{ }^{*} p<0.10$; standard errors clustered at the country level in brackets for specifications (1) and (2); specification (1) corresponds to Table 2, Panel B and C in McKenzie et al. (2014); observations in specifications (2) and (3) are weighted by the gender-specific number of migrants $m_{j t} ;{ }^{a}(2)$ and (3) refer to the specification in the table. The restricted version of the estimation equation assumes that all destination countries are equally substitutable for potential migrants. The unrestricted version allows for different patterns of substitution across destinations for potential migrants. Source: Authors' elaboration on the replication data from McKenzie et al. (2014). 
Table A.4: Migration regression by gender

\begin{tabular}{|c|c|c|}
\hline \multirow{3}{*}{$\begin{array}{l}\text { Specification } \\
\text { Variables } \\
\end{array}$} & \multicolumn{2}{|c|}{$\begin{array}{l}\text { Dependent variable: } \\
\qquad \ln \left(m_{j t}\right)\end{array}$} \\
\hline & Restricted & Unrestricted \\
\hline & $(1)$ & $(2)$ \\
\hline \multicolumn{3}{|l|}{ Panel A: Male sample } \\
\hline \multirow[t]{2}{*}{ Log GDP } & $1.15^{* *}$ & $3.61^{* * *}$ \\
\hline & {$[0.53]$} & {$[0.69]$} \\
\hline$H_{0}$ : Col. (1) nested in $(2)^{a} ; F$-test & \multicolumn{2}{|c|}{$5.72^{* * *}$} \\
\hline ( $p$-value) & \multicolumn{2}{|c|}{$(0.00)$} \\
\hline$H_{0}: \widehat{\psi}_{m}^{(1)}=\widehat{\psi}_{m}^{(2)} ; C h i^{2}$ test & \multicolumn{2}{|c|}{$7.14^{* * *}$} \\
\hline ( $p$-value) & \multicolumn{2}{|c|}{$(0.01)$} \\
\hline Observations & 972 & 972 \\
\hline Adjusted $R^{2}$ & 0.82 & 0.89 \\
\hline \multicolumn{3}{|l|}{ Panel B: Female sample } \\
\hline \multirow[t]{2}{*}{ Log GDP } & $1.98^{* * *}$ & $1.37^{* *}$ \\
\hline & {$[0.62]$} & {$[0.63]$} \\
\hline$H_{0}$ : Col. (1) nested in $(2)^{a} ; F$-test & \multicolumn{2}{|c|}{$5.99^{* * *}$} \\
\hline ( $p$-value $)$ & \multicolumn{2}{|c|}{$(0.00)$} \\
\hline$H_{0}: \widehat{\psi}_{m}^{(1)}=\widehat{\psi}_{m}^{(2)} ; C h i^{2}$ test & \multirow{2}{*}{\multicolumn{2}{|c|}{$\begin{array}{c}0.62 \\
(0.43)\end{array}$}} \\
\hline ( $p$-value) & & \\
\hline Observations & 972 & 972 \\
\hline Adjusted $R^{2}$ & 0.90 & 0.93 \\
\hline Country dummies & Yes & Yes \\
\hline Year dummies & Yes & Yes \\
\hline
\end{tabular}

Notes: ${ }^{* * *} p<0.01,{ }^{* *} p<0.05,{ }^{*} p<0.10$; standard errors clustered at the country level in brackets for specification (1); specification (1) corresponds to Table 2, Panel A in McKenzie et al. (2014); ${ }^{a}$ (1) and (2) refer to the specification in the table. The restricted version of the estimation equation assumes that all destination countries are equally substitutable for potential migrants. The unrestricted version allows for different patterns of substitution across destinations for potential migrants.

Source: Authors' elaboration on the replication data from McKenzie et al. (2014). 
Table A.5: Mean wages, omitting Japan

\begin{tabular}{lc|cc}
\multicolumn{3}{c}{$\begin{array}{c}\text { Dependent variable: } \\
\ln (\text { mean wages })\end{array}$} \\
Spestricted & Restricted & Unrestricted \\
Variables & $(1)$ & $(2)$ & $(3)$ \\
\hline & & & \\
$\log$ GDP & -0.07 & $0.58^{* * *}$ & $0.50^{* * *}$ \\
& {$[0.14]$} & {$[0.15]$} & {$[0.07]$} \\
& & & \\
Observations & 949 & 949 & 949 \\
Adjusted $R^{2}$ & 0.73 & 0.90 & 0.94 \\
Country dummies & Yes & Yes & Yes \\
Year dummies & Yes & Yes & Yes \\
Weights & No & Yes & Yes \\
\hline$H_{0}:$ Col. $(2)$ nested in $(3)^{a} ; F$-test & & \multicolumn{2}{|c}{$6.99^{* * *}$} \\
$(p$-value $)$ & & \multicolumn{2}{|c}{$(0.00)$} \\
$H_{0}: \widehat{\psi}_{w}^{(2)}=\widehat{\psi}_{w}^{(3)} ; C h i^{2}$ test & & \multicolumn{2}{|c}{0.19} \\
$(p$-value $)$ & & \multicolumn{2}{|c}{$(0.67)$}
\end{tabular}

Notes: ${ }^{* * *} p<0.01,{ }^{* *} p<0.05,{ }^{*} p<0.10$; standard errors clustered at the country level in brackets for specifications (1) and (2); observations in specifications (2) and (3) are weighted by $m_{j t} ;{ }^{a}(2)$ and (3) refer to the specification in the table. The restricted version of the estimation equation assumes that all destination countries are equally substitutable for potential migrants. The unrestricted version allows for different patterns of substitution across destinations for potential migrants.

Source: Authors' elaboration on the replication data from McKenzie et al. (2014). 
Table A.6: Median wages, omitting Japan

\begin{tabular}{|c|c|c|c|}
\hline \multicolumn{4}{|c|}{$\begin{array}{l}\text { Dependent variable: } \\
\ln (\text { median wages })\end{array}$} \\
\hline $\begin{array}{l}\text { Specification } \\
\text { Variables }\end{array}$ & $\begin{array}{c}\text { Restricted } \\
\text { (1) }\end{array}$ & $\begin{array}{l}\text { Restricted } \\
\quad(2) \\
\end{array}$ & $\begin{array}{c}\text { Unrestricted } \\
(3)\end{array}$ \\
\hline $\log$ GDP & $\begin{array}{l}-0.09 \\
{[0.16]}\end{array}$ & $\begin{array}{c}0.79^{* * *} \\
{[0.18]}\end{array}$ & $\begin{array}{c}0.68^{* * *} \\
{[0.08]}\end{array}$ \\
\hline Observations & 949 & 949 & 949 \\
\hline Adjusted $R^{2}$ & 0.70 & 0.89 & 0.94 \\
\hline Country dummies & Yes & Yes & Yes \\
\hline Year dummies & Yes & Yes & Yes \\
\hline Weights & No & Yes & Yes \\
\hline $\begin{array}{l}H_{0}: \text { Col. }(2) \text { nested in }(3)^{a} ; F \text {-test } \\
(p \text {-value) } \\
H_{0}: \widehat{\psi}_{w}^{(2)}=\widehat{\psi}_{w}^{(3)} ; C h i^{2} \text { test } \\
(p \text {-value })\end{array}$ & & & $\begin{array}{l}3 * * * \\
.00) \\
.25 \\
62)\end{array}$ \\
\hline
\end{tabular}

Notes: ${ }^{* * *} p<0.01,{ }^{* *} p<0.05,{ }^{*} p<0.10$; standard errors clustered at the country level in brackets for specifications (1) and (2); observations in specifications (2) and (3) are weighted by $m_{j t} ;{ }^{a}(2)$ and (3) refer to the specification in the table. The restricted version of the estimation equation assumes that all destination countries are equally substitutable for potential migrants. The unrestricted version allows for different patterns of substitution across destinations for potential migrants.

Source: Authors' elaboration on the replication data from McKenzie et al. (2014). 
Table A.7: Migration regression omitting Japan

Dependent variable

$$
\ln \left(m_{j t}\right)
$$

\begin{tabular}{lcc}
$\begin{array}{l}\text { Specification } \\
\text { Variables }\end{array}$ & $\begin{array}{c}\text { Restricted } \\
(1)\end{array}$ & $\begin{array}{c}\text { Unrestricted } \\
(2)\end{array}$ \\
\hline log GDP & $\begin{array}{c}1.34^{* * *} \\
{[0.47]}\end{array}$ & $\begin{array}{c}3.45^{* * *} \\
{[0.67]}\end{array}$ \\
& & \\
& 954 & 954 \\
Observations & 0.85 & 0.89 \\
Adjusted $R^{2}$ & Yes & Yes \\
Country dummies & Yes & Yes \\
Year dummies & \multicolumn{2}{c}{$4.77^{* * *}$} \\
\hline$H_{0}:$ Col. $(1)$ nested in $(2)^{a} ; F$-test & \multicolumn{2}{c}{$(0.00)$} \\
$(p$-value $)$ & \multicolumn{2}{c}{$5.97^{* *}$} \\
$H_{0}: \widehat{\psi}_{m}^{(1)}=\widehat{\psi}_{m}^{(2)} ; C h i^{2}$ test & \multicolumn{2}{c}{$(0.02)$} \\
$(p$-value $)$ & \multicolumn{2}{l}{}
\end{tabular}

Notes: ${ }^{* * *} p<0.01,{ }^{* *} p<0.05,{ }^{*} p<0.10$; standard errors clustered at the country level in brackets for specification (1); ${ }^{a}$ (1) and (2) refer to the specification in the table. The restricted version of the estimation equation assumes that all destination countries are equally substitutable for potential migrants. The unrestricted version allows for different patterns of substitution across destinations for potential migrants.

Source: Authors' elaboration on the replication data from McKenzie et al. (2014). 